\title{
STUDENTS' PERCEPTIONS TOWARD QUIZIZZ AS AN ONLINE LEARNING MEDIA
}

\author{
Sari Rahmawati \\ Faculty of Tarbiyah and Teacher Training, UIN Imam Bonjol Padang, 26223, Indonesia \\ (srahmawati59@yahoo.com)
}

\begin{abstract}
Indonesia adapted a new change in the education system since Pandemic COVID-19, especially for having online learning. The purpose of this study was to examine students' perceptions toward the use of Quizizz as an online learning media in English courses during the COVID-19 pandemic. The design of the study was descriptive qualitative. The subjects of the study were 89 Information Systems students of STMIK Jayanusa. The data was collected through a questionnaire on Google Forms and they were analyzed by using the Likert Scale. The study revealed that students responded to Quizizz use positively; they strongly agreed about the use of Quizizz in distance learning.
\end{abstract}

Keywords: Quizizz; Media; Online Learning

First Received:

(February 11, 2021)
Final Proof Received:

(March 30, 2021)

\section{INTRODUCTION}

Due to the COVID-19 pandemic, Indonesia adapted to a new change in the education system. The process of teaching and learning conducted normally in school has been moved to home or it is called online learning. This new system brings a "culture shock' for both teachers and students. Since everything is done virtually like class meetings and class discussion unlike normal class, there are some obstacles in this new activity. The first one is the internet connection problem; each area has different quality of internet connection problem. As the result, all information shared during the class can not be fully accepted for those who have a bad internet connection. Besides, since there is no direct interaction between teacher and student, it causes a lack of control from the teacher during the interface video conference with a large number of students. In other words, there are some communication pitfalls such as an inability to read gestures and faces that move into different spots on the screen (Morris, 2020). The last problem comes from the students. It is found that many students preferred face-to-face learning over online learning since they have situational and environmental challenges (Hermida, 2020). Before the COVID-19 outbreak, they used to go to school but they study at home and see the screen as a whole with more assignments right now.

In STMIK Jayanusa, all learning activities like learning material, assignment, quiz, discussion, and evaluation have been managing throughout e-learning provided by the institution during the pandemic. However, a problem is found in English courses; more 
than $50 \%$ of students are dishonest in their academic activities; they submit the same content for individual assignments. They seem to have a lack of interest in studying. As the result, they do not participate and are not engaged well with the lesson.

Information technology has a significant role in supporting education during COVID19 lockdown (Saxena et al., 2020). It can be seen that during this pandemic, distance and online education growing dramatically. E-learning platforms are a boon for education. Elearning can be defined as a program or course in which students receive some or all of their education over a networked system such as the internet (Burdette, Greer, \& Woods, 2013 cited in Rahmawati, 2016). A computer is not merely a device that supports elearning, other devices like smartphones and tablets can be utilized as well. Thus, the existence of cutting-edge technology accommodates home-learning.

To implement distance learning based on E-learning, there are several things to consider as proposed by (Saxena et al., 2020):

1. Designing multipurpose learning model.

2. Develop an inventory of digital content that can be deployed through remote learning.

3. Arrange E-contents in alignment with the curriculum of the respective university/college to make sure that the contents will meet the objective of the course.

4. Develop a helpdesk (virtual) to support students and teachers for interaction and to solve the queries.

5. Use printed study materials at home (if the physical distribution of the same is possible), if not then newspaper or social media can be used to provide materials.

6. Radio education can be a good way of interactive verbal education. This is especially useful in the area where either broadband connectivity is not there or the quality of it is very poor.

7. Recorded lectures of good quality teachers can be broadcast on television. These recordings can be re-run by the students if she/he does not understand any part of the lesson.

8. Enhance the digital infrastructure and bandwidth to promote remote learning.

9. For a particular syllabus, one portal must be there, where all the contents should be available to the students in a standard way that leads to ease of access.

10. The material should not be bound to one kind of device. It should be diverse in nature and available through TV, mobile, laptops, and tablets.

11. Optimize the learning tools for low bandwidth which will be very helpful in the current scenario.

12. Instead of long lectures, short, crisp, and quality lectures should be delivered online to engage all types of students.

13. Provide guideline manual to students and faculty to access the material from the portal. 
From the explanation above, teachers should choose the best media and material to meet learning outcomes amid some problems in remote learning. The effectiveness of chosen e-learning is determined by students' motivation and students' engagement with the e-leaning (Noesgaard \& Ørngreen, 2015). Under it, friendly platforms are required to increase students' participation (Agung et al., 2020). Students' participation in class is influenced by motivation. The more positive motivation causes the higher effective participation(Tasgin \& Tunc, 2018). Hence, if the lessons are designed by considering students' motivation, they will be less disaffected in the lesson.

Riswanto \& Aryani (2017: 44) state that the use of creative and fun technology influences students' motivation. As motivation plays an important role in learning, gamification is best implemented in e-learning systems (Strmečki et al., 2020). In their study, it is revealed that gamified version of the online module gives learning success to students. A similar result was also found by (Poondej \& Lerdpornkulrat, 2019: 13); it is reported that students were more engaged in the gamified e-learning course. In line with that, (Vu et al., 2014: 235) state that integrating games into the online learning setting has the potential to elevate learning to a new level, helping students achieve a higher degree of engagement in their online courses.

Concerning all principles and suggestions in choosing an effective and appropriate media during distance learning, the author has chosen an alternative medium, namely Quizizz. It has been used in English courses for five weeks. Hence, the author was interested to examine STMIK Jayanusa students' responses, especially Information System students toward the use of Quizizz in English courses.

\section{LITERATURE REVIEW}

Quizizz is a game-based application for education that can be played by multiplayer as e-learning and it can create fun and interactive classroom (Pahamzah et al., 2020). Quizizz has gamification characteristics like avatars, themes, memes, and music that can boost joyful learning. Even though the students are in remote learning, they can take the Quizizz together at the same time via computer, laptop, smartphone, or tablet by entering the code and they can see their live ranking on the leader board.

Quizizz can be designed in different formats like true or false, multiple choices, and fill in the blanks (Zhao, 2019). Teachers can set the game in some ways, such as turning on or off the background music, ranking based on correction rate only or both correction rate and time used for completing the Quizizz, ranking showing all the students or only top five students, shuffle questions, or not. Dealing with the feature of shuffling questions, students can not cheat each other so that the final score reflects their understandings in the lesson. After a Quizizz session finish, students can review all the questions (with both their answers and solutions). What is more interesting is the Quizizz reports are available on the website and can be downloaded as Excel files. 


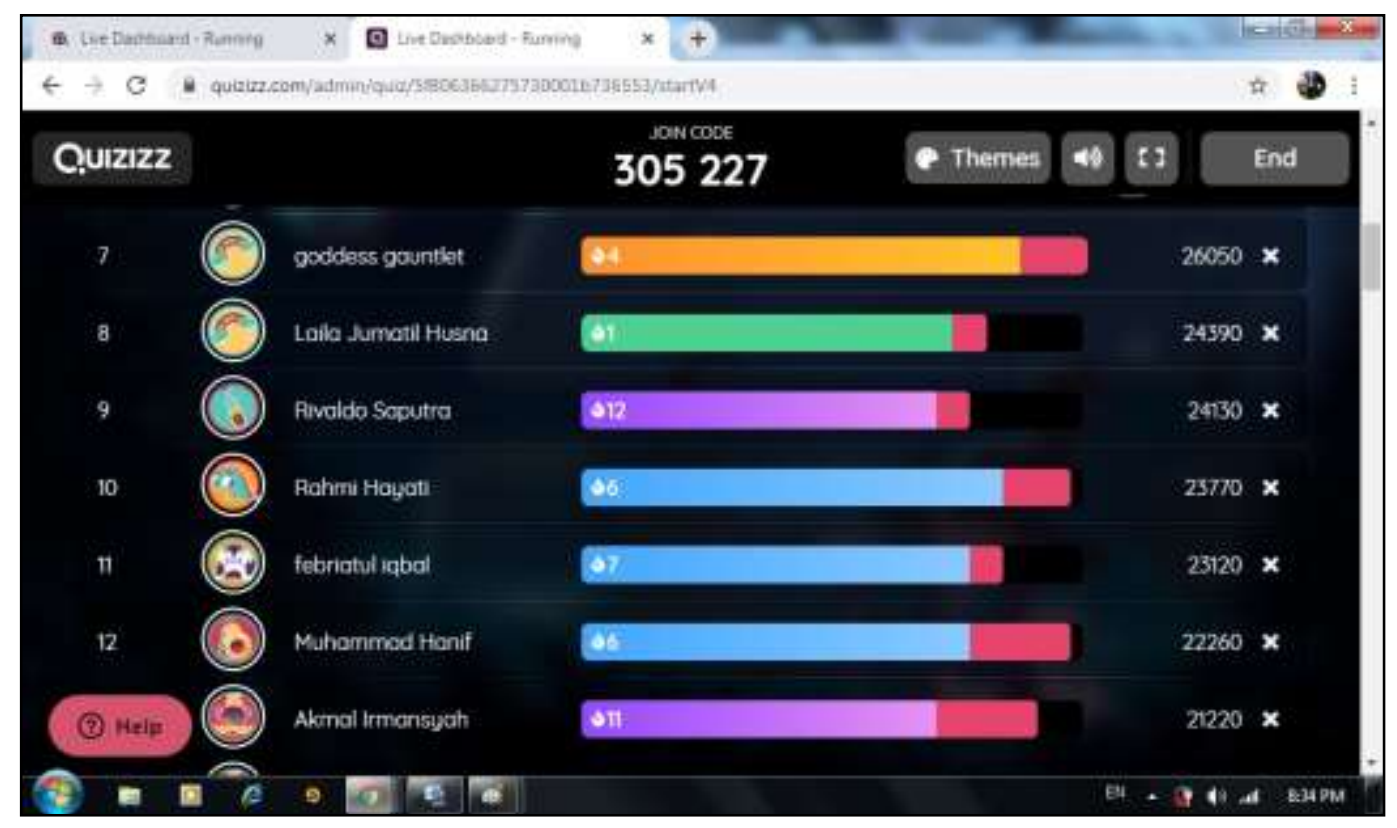

Fig 1. Quizizz Leader Board

Numerous studies proved that Quizizz has been successful in promoting students' learning. Priyanti et al., (2019: 79) reported that Quizizz affected students' reading comprehension in English positively. Other research by Suharsono (2020: 340) compared the use of Quizizz and Kahoot! showed that Quizizz is more preferable to Kahoot since Quizizz has superior features like leaderboard game and correct answer after the game finished. Furthermore, Rahayu \& Purnawarman (2019: 106) claimed that students were able to identify their strengths and weaknesses in grammar prompted by Quizizz: do the first Quizizz -received feedback - review - reply Quizizz - do the next Quizizz. Students can improve their grammar understandings after taking the Quizizz. From these several studies, it can be concluded that Quizizz as gamified application gives a positive impact on students.

\section{METHOD}

This research was survey research. Pinsonneault and Kraemer in Glasow (2005: 44) defined a survey as a "means for gathering information about the characteristics, actions, or opinions of a large group of people". The focus of this research was students' perceptions toward Quizizz application that involved 89 Information Systems students of STMIK Jayanusa in the third semester registered in the 2020/2021 academic year. The questionnaire was distributed to all participants on Google Forms and it was analyzed by using the Likert scale.

To analyze the data, scoring was done first. The Likert scale consists of five statements; they are Strongly Agree (SA), Agree (A), Neutral (N), Disagree (D), and Strongly Disagree (SD). Each statement has different point; 5 (SA), 4 (A), 3 (N), 2 (D), and 1 (SD). After that, the researcher calculated the score range for each questionnaire as 
follows: maximum score: 10 × 89 × $5=4450$, and minimum score: $10 \times 89$ × $1=890$, and score range (R): $4450-89=3560$. Then, the researcher determined the criteria of score interpretation of each questionnaire set. Finally, the researcher described the data in narrative form. The total score interpretation can be seen in the following table:

Table 1.

Total Score Interpretation

\begin{tabular}{ll}
\hline Score & Interpretation \\
\hline $4450-3561$ & Strongly agree \\
$3560-2671$ & Agree \\
$2670-1781$ & Neutral \\
$1780-891$ & Agree \\
890 & Strongly disagree \\
\hline
\end{tabular}

\section{RESULTS AND DISCUSSION}

\section{Results}

From the questionnaire, it was revealed that students' perceptions toward Quizizz using during home learning was mostly neutral. The detailed results are shown in the following table.

Table 2.

Students' Perceptions toward Quizizzas an Online Learning Media

\begin{tabular}{|c|c|c|c|c|c|c|c|c|}
\hline No & Item & SD & $\mathbf{D}$ & $\mathbf{N}$ & A & SA & HS & I \\
\hline 1 & Quizizz is easy to use & - & - & 11 & 17 & 61 & 3050 & $\mathrm{~A}$ \\
\hline 2 & $\begin{array}{l}\text { Quizizz helps me review the } \\
\text { course material in online learning }\end{array}$ & 1 & 2 & 8 & 37 & 41 & 2050 & $\mathrm{~N}$ \\
\hline 3 & $\begin{array}{l}\text { Quizizz is effective in enhancing } \\
\text { my engagement in English course in } \\
\text { online learning }\end{array}$ & 1 & 2 & 9 & 38 & 39 & 1950 & $\mathrm{~N}$ \\
\hline 4 & $\begin{array}{l}\text { Quizizz stimulates my interest in } \\
\text { learning English during online learning }\end{array}$ & - & 1 & 15 & 35 & 38 & 1900 & $\mathrm{~N}$ \\
\hline 5 & Doing exercises on Quizizz is fun & - & - & 11 & 32 & 46 & 2300 & $\mathrm{~N}$ \\
\hline 6 & Quizizz has an attractive display & - & - & 7 & 44 & 38 & 2200 & $\mathrm{~N}$ \\
\hline 7 & $\begin{array}{l}\text { Quizizz feels like a game so that } \\
\text { I do not get any fatigue and boredom } \\
\text { while I use it }\end{array}$ & - & - & 8 & 29 & 52 & 2600 & $\mathrm{~N}$ \\
\hline 8 & $\begin{array}{l}\text { The ranking function (leader board) } \\
\text { in Quizizz motivates me to study }\end{array}$ & - & - & 6 & 29 & 54 & 2700 & A \\
\hline 9 & $\begin{array}{l}\text { Due to in real-time exercises, I can not } \\
\text { cheat so that I always try to get top scores } \\
\text { in Quizizz }\end{array}$ & - & - & 6 & 33 & 50 & 2500 & $\mathrm{~N}$ \\
\hline
\end{tabular}


10 Quizizz is better than any online learning

\begin{tabular}{lllllll}
- & - & 10 & 41 & 38 & 2050 & $\mathrm{~N}$ \\
& & & & & & \\
2 & 5 & 91 & 335 & 457 & & \\
2 & 10 & 273 & 1340 & 2285 & \\
\hline & & & & $\mathbf{3 9 1 0}$ & SA
\end{tabular}
media, especially as a media to do exercises

Score $(S)$

Score X Option Value

Total Score

Note: $\mathrm{HS}=$ Highest Score, $\mathrm{I}$ = Interpretation

From the table above, the students' perception on eight of ten statements was neutral. Those statements are Quizizz helps me review the course material in online learning, Quizizz is effective in enhancing my engagement in English course during online learning, Quizizz stimulates my interest in learning English during online learning, doing exercises on Quizizz is fun, Quizizz has an attractive display, Quizizz feels like a game so that I do not get any fatigue and boredom while I use it, due to in real-time exercises, I can not cheat so that I always try to get top scores in Quizizz, and Quizizz is better than any online learning media, especially as a media to do exercises.

On the other hand, the rest of the statements were agreed by the students, they are Quizizz is easy to use and the ranking function (leader board) in Quizizz motivates me to study. The sum of the questionnaire result was 3910, which was interpreted s strongly agree. That score was derived by multiplying the score with the option value, and then sum it up.

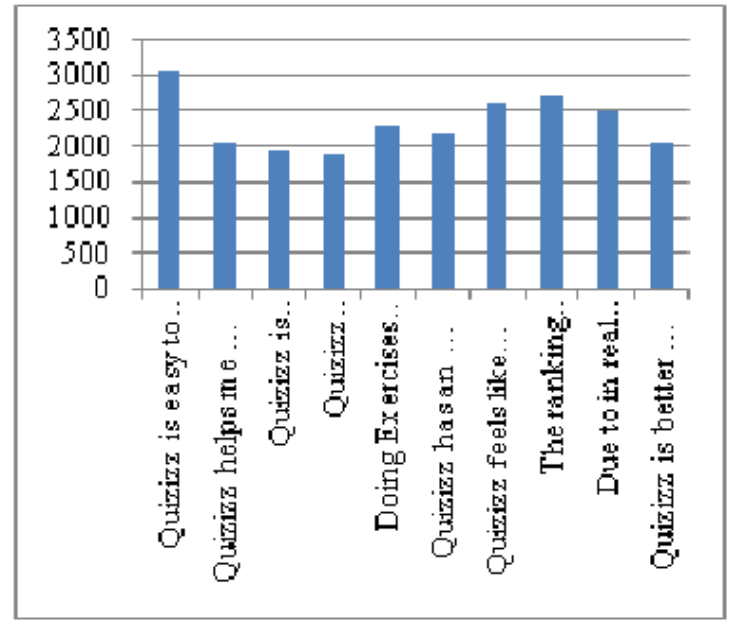

Fig. 2. The Highest Score of Each Statement in the Questionnaire

The highest score is obtained by multiplying the highest number of the students' responses with the option value. Then, it is multiplied by ten. For instance, the first statement in the questionnaire, Quizizz is easy to use, was strongly agreed by sixty-one students, agreed by seventeen students, and responded neutrally by eleven students. To get the highest score from the first statement is as followed $61 \times 5=305 ; 305 \times 10=3050$. The obtained score, 3050 , is interpreted as agree according to the Likert Scale. 
From the highest score, it can be seen that two statements were agreed by the students. They are Quizizz is easy to use and the ranking function (leader board) in Quizizz motivates me to study. The rest of the statements were responded as neutral by the students: Quizizz helps me review the course material in online learning, Quizizz is effective in enhancing my engagement in English course in online learning, Quizizz stimulates my interest in learning English during online learning, doing exercises on Quizizz is fun, Quizizz has an attractive display, Quizizz feels like a game so that I do not get any fatigue and boredom while I use it, due to in real-time exercises, I can not cheat so that I always try to get top scores in Quizizz, and Quizizz is better than any online learning media, especially as a media to do exercises.

\section{Discussion}

The students showed their positive responses toward Quizizz as one of the applications in online learning. It can be seen from the total score of the questionnaire result. The total score was 3910 which was interpreted as strongly agreed. The result of this study was similar to the previous study conducted by Wibawa et al., (2019: 252) that the students gave positive responses to Quizizz since it provides interactive quiz games as a learning medium.

A statement which agreed the most by the students was Quizizz is easy to use. It was in line with Wibawa et al., (2019: 252) study previously that students have easier access to Quizizz by entering the join code; soon they can access the exercises on it. Apart from that, they can access it whenever and wherever they are so that this application is really helpful as an online learning medium.

The next statement agreed by the students was the ranking function (leader board) in Quizizz motivates me to study. Quizizz provides a leader board that shows students' ranking based on gained points from the questions. Hence, each student knows where she/he so that she/he tries to take the lead. The first time they experienced Quizizz in online learning, they were excited about the results on the leader board. One of them sent a chat in Whatsapp group class, "Marion took the lead, next time I will take over." It shows that they have the enthusiasm and intend to study more for such a competitive game through Quizizz.

Eight statements were responded as neutral by the students. Those statements are categorized into two groups. The first one is Quizizz helps me review the course material in online learning, Quizizz is effective in enhancing my engagement in English course in online learning, Quizizz stimulates my interest in learning English during online learning, doing exercises on Quizizz is fun, Quizizz has an attractive display, Quizizz feels like a game so that I do not get any fatigue and boredom while I use it, and Quizizz is better than any online learning media, especially as a media to do exercises. These are possible because they have experienced various media in online learning of different courses. Thus, 
they have a preference of which media can help them a lot to review the course material and give a better learning experience than Quizizz in distance learning.

The last group categorized into neutral-responded by the students consists of one statement, that is, due to in real-time exercises, I can not cheat so that I always try to get top scores in Quizizz. Due to the Quizzizz setting enables the host to shuffle the questions; the students do not have the opportunity to be dishonest during Quizizz live session. They have to work their way up to be the best on Quizizz.

\section{CONCLUSION}

In brief, most of the third-semester students in the academic year 2020/2021 at STMIK Jayanusa strongly agreed toward the use of Quizizz as an online learning media. They are more motivated and engaged well in the course. However, another alternative online media should be experienced by the students in English courses so that they can have meaningful and joyful learning during the pandemic.

\section{REFERENCES}

Agung, A. S. S. N., Surtikanti, M. W., \& OP, C. A. Q. (2020). Students' Perception of Online Learning during COVID-19 Pandemic: A Case Study on the English Students of STKIP Pamane Talino. Journal of Social Sciences and Humanities, 10(2). http://ojs.pnb.ac.id/index.php/SOSHUM/article/view/1316

Glasow, P. A. (2005). Glasow, P. A. (2005). Fundamental of Survey Research Methodology. Virginia: MITRE. MITRE.

Hermida, P. A. (2020). College Students' Use and Acceptance of Emergency Online Learning due to COVID-19. International Journal of Educational Research, 2(3), 2635.

Morris, B. (2020, May 27). Why Does Zoom Exhausted You? Science Has an Answer. Why Does Zoom Exhausted You? Science Has an Answer. https://wwqw.google.com/amp/s/www.wsj.com/amp/articles/why-does-zoomexhausted-you-science-has-an-answer-11590600269

Noesgaard, S. S., \& Ørngreen, R. (2015). Noesgaard, S. S. \& Ǿrngreen, R. (2015). The Effectiveness of E-Learning: An Explorative and Integrative Review of the Definitions, Methodologies and Factors that Promote E-Learning Effectiveness. Electronic Journal of e-Learning, 13(4), 278-290. Electronic Journal of E-Learning, 13(4), 278-290.

Pahamzah, J., Syafrizal, S., Juniardi, Y., \& Sukaenah, P. M. (2020). Quizizz as a Students' Reading Comprehension Learning Media: A Case Study at the Eleventh Grade of Dwi Putra Bangsa Vocational School In Cimanggu. International Journal of English Language and Linguiatics Research, 8(5), 27-33. International Journal of English Language and Linguistics Research, 8(5), 27-33.

Poondej, C., \& Lerdpornkulrat, T. (2019). Poondej, C. \& Lerdpornkulrat, T. (2019). Gamification in E-Learning: A Moodle Implementation and Its Effect on Students Engagement and Performance. Interactive Technology and Smart Educartion, 17(1). 56-66. Doi: 10.1198?ITSE-06-2019-0030. Interactive Technology and Smart Educartion, 17(1), 56-66. https://doi.org/10.1198?ITSE-06-2019-0030 
Priyanti, N. W. I., Santosa, M. H., \& Dewi, K. S. (2019). Effect of Quizizz Toward the EleventhGrade English Students' Reading Comprehension in Mobile Learning Context. LEJU, 2(2), 71-80. 2(2), 71-80.

Rahayu, I. S. D., \& Purnawarman, P. (2019). The Use of Quizizz in Improving Students' Grammar Understanding through Self-Assessment. Eleventh Conference on Applied Linguistics (CONAPLIN 2018), 102-106.

Rahmawati, F. (2016). E-learning Implementation: Its Opportunities and Drawbacks Perceived by EFL Students. Journal of Foreign Language, Teaching, and Learning, 1(1), 1-15. Journal of Foreign Language, Teaching, and Learning, 1(1), 1-15.

Riswanto, A., \& Aryani, S. (2017). Learning Motivation and Student Achievement: Description Analysis and Relationships both. COUNS-EDU-The International Journal of Counseling and Education, 2(1), 42-47. https://doi.org/0.23916/002017026010

Saxena, R., Kaur, P. P., \& Saxena, A. (2020). Role of Information Technology in Education during COVID-19. International Journal of Advance Science and Technology, 29(8), 4071-4078.

Strmečki, D., Bernik, A., \& Radošević, D. (2020). Gamification in E-learning: Introducing Gamified Design Elements into E-Learning Systems. Journal of Computer Sciences, 11(120), 108-117. https://doi.org/10.3844/jcssp.2015.1108.1117

Suharsono, A. (2020). The Use of Quizizz and Kahoot! In the Training for Millenial Generation. IJIET, 4(2), 332-342. Doi: 10.24071/ijiet.2020.040215. 4(2), 332-342. https://doi.org/10.24071/ijiet.2020.040215

Tasgin, A., \& Tunc, Y. (2018). Effective Participation and Motivation: An Investigation on Secondary School Students. World Journal of Education, 8(1), 58-74.

Vu, P., Crow, S. R., \& Fredrickson, S. (2014). Using Games in Online Education: is it A Winning Strategy?. Online Journal of Distance Learning Administration, 17(6), 226237. Online Journal of Distance Learning Administration, 17(6), 226-237.

Wibawa, R. P., Astuti, R. I., \& Pangestu, B. A. (2019). Smartphone-Based Application "Quizizz" as A Learning Media. , 14(2), 244-253. Dinamika Pendidikan, 14(2), 244253. https://doi.org/10.15294/dp.v14i2.23359

Zhao, F. (2019). Zhao, F. (2019). Using Quizizz to Integrate Fun Multiplayer Activity in the Accounting Classroom. International Journal of Higher Education, 8(1), 37-43. Https://doi.org/10.5430/ijhe.v8n1p37. International Journal of Higher Education, 8(1), 37-43. 